\title{
Front Matter: Volume 11891
}

, "Front Matter: Volume 11891," Proc. SPIE 11891, Semiconductor Lasers and Applications XI, 1189101 (3 November 2021); doi: 10.1117/12.2619274

SPIE. Event: SPIE/COS Photonics Asia, 2021, Nantong, Jiangsu, China 


\title{
PRO CEEDINGS OF SPIE
}

\section{Semic onductor Lasers and Applications XI}

\author{
Wei $\mathbf{L}$ \\ Wemer H. Hofmann \\ Yikai Su \\ Editors
}

\section{0-12 October 2021 Nantong, China}

\author{
Sponsored by \\ SPIE \\ COS-Chinese Optical Society
}

\section{Cooperating Organizations}

Tsing hua University (China) • Peking University (China) • University of Science and Technology of China (China) • Zhejiang University (China) • Tianjin University (China) • Beijing Institute of Technology (China) • Beijing University of Posts and Telec ommunic a tions (China) • Nankai University (China) • Chang chun University of Sc ience and Technology (China) University of Shanghai for Sc ience and Technology (China) - Capital Nomal University (China) • Huazhong University of Science and Technology (China) - Beijing J iaotong University (China) • China Jiliang University (China) - Shanghai Institute of Optics and Fine Mechanics, CAS (China) - Changchun Institute of Optics, Fine Mechanics and Physics, CAS (China) Institute of Semic onductors, CAS (China) - Institute of Optics and Electronic s, CAS (China) - Institute of Physics, CAS (China) - Shanghai Institute of Technic al Physics, CAS (China) - China Instrument and Control Society (China) • The Optical Society of Japan (Japan) - Optical Society of Korea (Korea, Republic of) - Australia and New Zealand Optical Society (Australia) Optics and Photonic s Society of Singapore (Singapore) • European Optic al Soc iety

Supporting Organizations

China Association for Science and Technology (CAST) (China)

Department of Information of National Nature Science Foundation, China (NSFC) (China)

Published by

SPIE

Volume 11891 
The papers in this volume were part of the technical conference cited on the cover and title page. Papers were selected and subject to review by the editors and conference program committee. Some conference presentations may not be available for publication. Additional papers and presentation recordings may be available online in the SPIE Digital Library at SPIEDigitalLibrary.org.

The papers reflect the work and thoughts of the authors and are published herein as submitted. The publisher is not responsible for the validity of the information or for any outcomes resulting from reliance thereon.

Please use the following format to cite material from these proceedings:

Author(s), "Title of Paper," in Semiconductor Lasers and Applications XI, edited by Wei Li, Werner H. Hofmann, Yikai Su, Proc. of SPIE 1 1891, Seven-digit Article CID Number (DD/MM/YYYY); (DOI URL).

ISSN: 0277-786X

ISSN: 1996-756X (electronic)

ISBN: 9781510646315

ISBN: 9781510646322 (electronic)

Published by

SPIE

P.O. Box 10, Bellingham, Washington 98227-0010 USA

Telephone +1 3606763290 (Pacific Time)

SPIE.org

Copyright (C) 2021 Society of Photo-Optical Instrumentation Engineers (SPIE).

Copying of material in this book for internal or personal use, or for the internal or personal use of specific clients, beyond the fair use provisions granted by the U.S. Copyright Law is authorized by SPIE subject to payment of fees. To obtain permission to use and share articles in this volume, visit Copyright Clearance Center at copyright.com. Other copying for republication, resale, advertising or promotion, or any form of systematic or multiple reproduction of any material in this book is prohibited except with permission in writing from the publisher.

Printed in the United States of America by Curran Associates, Inc., under license from SPIE.

Publication of record for individual papers is online in the SPIE Digital Library.

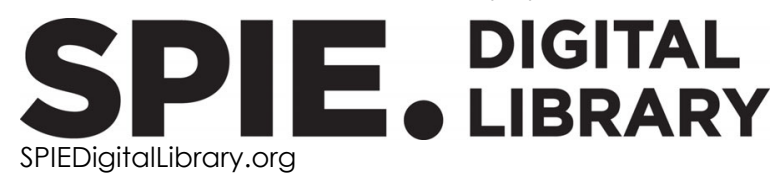

Paper Numbering: A unique citation identifier (CID) number is assigned to each article in the Proceedings of SPIE at the time of publication. Utilization of CIDs allows articles to be fully citable as soon as they are published online, and connects the same identifier to all online and print versions of the publication. SPIE uses a seven-digit CID article numbering system structured as follows:

- The first five digits correspond to the SPIE volume number.

- The last two digits indicate publication order within the volume using a Base 36 numbering system employing both numerals and letters. These two-number sets start with 00, 01, 02, 03, 04, $05,06,07,08,09,0 A, 0 B \ldots$.. OZ, followed by 10-1Z, 20-2Z, etc. The CID Number appears on each page of the manuscript. 


\section{Contents}

APPUCATIONS OF LASER DIODES I

1189102 Optical domain control-based frequency chiped microwave waveform generation and antidispersion transmission overoptical fiber (Invited Paper) [11891-1]

1189103 Camier phase recovery in optical fiber communication systems using high-order modulation formats [11891-2]

1189104 Fiber-optic communication method applied to high-temperature environment [11891-3]

\section{APPUCATIONS OF LASER DIODES II}

1189106 Accuracy of EGN model in ultra-wideband optical fiber communication systems [11891-5]

$1189107 \quad$ Influence of equalization enhanced phase noise on digital nonlinearity compensation in Nyquist-spaced superchannel transmission systems [11891-6]

1189108 A scheme for generating mult-channel chaotic signals with time-delay signature suppression [11891-8]

1189109 Evaluation of transmission reach and information rates in nonlinearoptical fiber communication systems [11891-9]

\section{SEMICONDUCTOR LASERS I}

$11891 \mathrm{OB} \quad$ Iterative leaming pre-distortion linearization for hybrid integrated frequency-modulated continuous-wave laser source [11891-11]

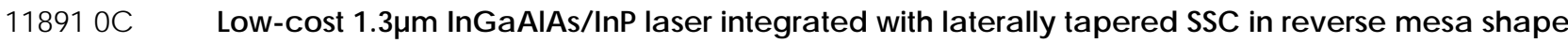
[11891-12]

11891 OD Structural optimization of reducing the themal stress and Smile in packaging a high-power diode laser amay on a mic roc hannel cooler using gold-tin hard solder [11891-13]

11891 OF Gain-switched pulses from quantum-dot laser exc ited state [11891-15] 
$11891 \mathrm{OH} \quad$ VCSEL line-beam module for LDAR applications [11891-17]

\section{SUBSYSTEMS USING LASER DIODES I}

$118910 \mathrm{~K}$ Self-calibrated electrical spectrum measurement of optical frequency comb based on segmental electro-optic up-conversion (Invited Paper) [11891-20]

11891 OM Handwritten numeral recognition utilizing optoelectronic reservoir computing with double resenoir layers [11891-22]

11891 ON Secunity-enhanced high-speed messages transmission based on chaos synchronization system with phase modulation and phase-to-intensity conversion [11891-23]

\section{SUBSYSTEMS USING LASER DIODES II}

$1189100 \quad$ Optical frequency comb generation by mutual injection in twin-stripe semic onductor laser [11891-24]

$118910 Q \quad$ Six-primary-laser projection display system compatible with 3D and 2D display [11891-26]

$118910 R \quad$ Numerical investigation on the frequency-modulated continuous-wave generation based on a semic onduc tor laser under optic al injection from a direc ty c urrent-modulated semic onduc tor laser[11891-27]

11891 OS Research on VCSEl transmitter modules for intelligent driving [11891-28]

\section{POSTER SESSION}

11891 OT Hybrid integrated modulation bandwidth enhanced laser based on self-injection locking to an extemal high-Q mic roring refiector[11891-29]

$118910 \mathrm{U}$ The wavelength tuning perfomance of namow-linewidth laser-diode coupled to an extemal high-Q Si3N4 micro-ring resonator [11891-30]

11891 OV Hertz-linewidth hybrid integrated laser based on high-Q Si3 $\mathbf{N}_{4}$ mic roring refiectors [11891-31]

11891 0W Laser phase noise measurement based on modified self-homodyne optical coherent receiver with a Faraday rotating mimor [11891-32]

$118910 X \quad$ Characterization of mic rowave interaction in electroabsoption-modulated DFB lasers [11891-33] 
1189111 Dynamics of self-injection locked multimode diode laser[11891-37]

Proc. of SPIE Vol. $118911189101-5$

Downloaded From: https://www.spiedigitallibrary.org/conference-proceedings-of-spie on 26 Apr 2023 Terms of Use: https://www.spiedigitallibrary.org/terms-of-use 
Proc. of SPIE Vol. 11891 1189101-6

Downloaded From: https://www.spiedigitallibrary.org/conference-proceedings-of-spie on 26 Apr 2023 Terms of Use: https://www.spiedigitallibrary.org/terms-of-use 